\title{
Sanajärjestyksen variaatiosta suomenoppijoiden teksteissä
}

\author{
MIKKO KAJANDER \\ Wienin yliopisto
}

Tiivistelmä. Ulkomaalaiselle suomenoppijalle lienee tuttua, että suomen kielen sanajärjestys on ainakin syntaktisesti melko vapaa. Toisaalta sanajärjestyksen variaatio ei ole mielivaltaista, vaan sillä on runsaasti tekstiyhteyteen ja lauseen informaatiorakenteeseen liittyviä tehtäviä, joita varmasti ainakin edistyneemmän suomenoppijan olisi hyvä hallita.

Tässä artikkelissa tutkimuskohteena on eksistentiaalilauseen (e-lauseen) sanajärjestys suomenoppijoiden kirjoittamissa teksteissä, jotka on arvioitu EVK:n mukaisille taitotasoille. Selvästi yleisimpiä e-lauseita aineistossa ovat (A)VS-muotoiset, sanajärjestykseltään tunnusmerkittömät eksistentiaalilauseet. Sanajärjestyksen variaatio kuitenkin lisääntyy kirjoitustaidon tason kasvaessa. Tutkin lähemmin tekstiyhteydessään SV-muotoisia ilmiölauseita, joissa siis subjekti edeltää verbiä. Lähestyn tätä sanajärjestystä ISK:ssa esitetyn kenttäkuvauksen avulla. Lähempi tarkastelu osoittaa, että myös suomenoppijat kykenevät käyttämään tunnusmerkkistä sanajärjestystä ja luomaan sen avulla tekstiyhteyteen sopivia lisämerkityksiä, esimerkiksi kontrastiivisuutta tai vakuuttelevan sävyn. Toisaalta e-subjektin sijoittaminen verbin edelle ei välttämättä teekään sanajärjestyksestä tunnusmerkkistä. Vaikka e-subjektia ja jopa koko ilmiölausetta on pidetty remaattisena, verbinetistä e-subjektia käytetään myös lauseen teemana. Joidenkin verbien yhteydessä tämä saattaa olla vakiintunutta.

Avainsanat: suomi toisena kielenä; S2; eksistentiaalilause; informaatiorakenne; kenttäkuvaus; Eurooppalainen viitekehys; Cefling 


\section{Johdanto}

Suomen kielen sanajärjestys on, kuten tunnettua, syntaktisesti melko vapaa, mutta toisaalta sanajärjestyksellä on luonnehdittu olevan myös temaattisia ja kontekstuaalisesti sidonnaisia tehtäviä (Hakulinen 1975; 2001 [1976]), ts. sanajärjestys kertoo lauseen informaatiorakenteesta ja tehtävästä diskurssissa (ISK 2004: 1304, vrt. Vilkuna 1989 ja Shore 2008). Keskeistä on lisäksi, että jotakin sanajärjestystä voi pitää neutraalimpana kuin toisia. Tieto siitä, mikä sanajärjestys on neutraali (tunnusmerkitön) ja millaisen tulkinnan muunlainen (tunnusmerkkinen) sanajärjestys aiheuttaa kontekstissaan, tuntuu kuuluvan syntyperäisen suomenpuhujan kielikompetenssiin. Jos taas suomea oppii toisena tai vieraana kielenä, suomen sanajärjestyksen tunnusmerkkisyyttä tai tunnusmerkittömyyttä, saati sanajärjestyksen yhteyttä informaatiorakenteeseen, ei välttämättä ole yhtä helppoa hahmottaa.

Tässä artikkelissa keskityn eksistentiaalisiin lauseisiin (e-lauseisiin) suomenoppijoiden kirjoittamissa teksteissä. Aineistonani on ns. Ceflingkorpus, jossa on yleisissä kielitutkinnoissa kerättyjä aikuisten tekstejä (669 kpl taitotasoilla A1-C2, 53019 sanetta) sekä koululaisten kirjoittamia tekstejä (527 kpl taitotasoilla A1-B2, 26063 sanetta). (Korpuksesta tarkemmin ks. Martin ym. 2010.) Tästä aineistosta on aiemmin tutkittu e-lauseissa esiintyviä kielenpiirteitä, joista voisi päätellä "Eurooppalaisen viitekehyksen” (2012, jäljempänä EVK) mukaisen kirjoitustaidon tason (Kajander 2013). Tutkimuksesta ilmenee, että e-lauseissa on joitakin sellaisia kielenpiirteitä, joita voi pitää kirjoitustaidon tason indikaattorina erityisesti A- ja B-tasoilla (tarkemmin mts. 210-215).

Koska e-lauseita tarkastellaan em. tutkimuksessa kontekstista irrallaan, ei sanajärjestykseen oteta siinä kantaa. Sanajärjestys ja sen variaatio ovat kuitenkin tämän artikkelin keskiössä. Keskityn tässä yhteydessä vain e-lauseiden sanajärjestykseen. E-lauseet eivät tietenkään yksinään kuvaa kokonaisen tekstin sanajärjestyksen variaatiota mutta tarjoavat silti hyvän lähtökohdan, sillä e-lauseen neutraali sanajärjestys on pitkälti vakiintunut. Esimerkiksi Hakanen (1972: 46-50) on todennut 
tämän "normaalipainotteisen" sanajärjestyksen e-lauseissa selvästi yleisimmäksi tutkittuaan kaunokirjallista aineistoa. Myöhemmin sanajärjestyksen variaatiossa on pyritty ottamaan huomioon e-lauseen informaatiorakenne lähinnä teoreettiselta kannalta tutkimatta lauseita laajemmassa tekstiyhteydessään (esim. Vähämäki 1984: 445-462; Huumo \& Perko 1993; Huumo 1997). Sen sijaan oppijankielen e-lauseiden sanajärjestystä tutkittaessa on kiinnitetty huomiota siihenkin, milloin epäprototyyppistä sanajärjestystä esiintyy. Ivaskan $(2009 ; 2010)$ mukaan lauseen kielteisyys sekä lauseessa olevat kontekstiin viittaavat tekijät saattavat toimia epäprototyyppisen SV-sanajärjestyksen myötäesiintyminä e-lauseissa.

On selvää, että sanajärjestystä täytyy kuitenkin tutkia lausetta laajemmassa kontekstissa, mikäli aikoo päästä selville siitä, ovatko erilaiset sanajärjestysvaihtoehdot kohdekielen mukaisia ja miten sanajärjestys mahdollisesti palvelee lauseen informaatiorakennetta. Pyrin tässä artikkelissa havainnollistamaan sitä, kuinka "Isossa suomen kieliopissa" (ISK 2004: 1306-1345) esitetty kenttäkuvaus soveltuu oppijankielen tekstien analyysiin. Perinteiset syntaktiset kategoriat ylittävä malli voi auttaa kielenoppijaa tulkitsemaan sanajärjestyksen tunnusmerkkisyyttä ja rakentamaan merkityksiä lausetta laajemmassa kontekstissa. Kenttäkuvausta ei ole juurikaan sovellettu oppijankielen tutkimukseen, poikkeuksena kuitenkin Toikka (2012), joka on eritellyt partikkeleiden paikkaa ja käyttöä oppijankielen lauseissa.

Esittelen eksistentiaalilauseen tavallisimmat, tunnusmerkittömät sanajärjestysvaihtoehdot ensin kontekstista irrallaan ja luon sen jälkeen yleisluontoisen kuvan e-lauseiden sanajärjestyksen variaation kehityksestä EVK:n (2012) mukaisilla kirjoitustaidon tasoilla. Vasta sen jälkeen siirryn tarkastelemaan joitakin tunnusmerkkisiä sanajärjestysvaihtoehtoja kontekstissaan. Käyn läpi muutamia sellaisia tapauksia, joissa kirjoittajat osaavat varioida e-lauseen sanajärjestystä kohdekielen mukaisella tavalla. Lopuksi nostan esille myös joitakin kysymyksiä, jotka liittyvät sanajärjestykseen ja sen variaatioon opittavana kielenpiirteenä. 


\section{E-lauseen tunnusmerkitön ja tunnusmerkkinen sanajärjestys ISK:n kenttäkuvauksessa}

Sanajärjestyksen kenttäkuvauksessa keskeiseen rooliin nousee lauseen informaatiorakenne. Mallin ideana on tarkastella sanajärjestyksen vaihtelua erillään lausekkeen lauseenjäsentehtävästä (ISK 2004: 1306). Perinteisesti S2-opetuksessa lauserakennetta on lähestytty kuitenkin lauseenjäsenten kautta. Oppiakseen esimerkiksi partitiivin käyttöä kielenoppijan täytyy osata hahmottaa lauseesta sellaiset kieliopilliset kategoriat kuin subjekti, objekti ja predikatiivi sekä tunnistaa lausetyyppi. Tämä saattaa auttaa kohdekielen mukaisen sijamuodon valinnassa, mutta erityisesti edistyneemmän oppijan, joka kohtaa ja kirjoittaa pitempiä tekstejä ja lauseita, olisi varmasti myös opittava hahmottamaan lauseen informaatiorakenne. Erityisesti pitemmässä tekstissä on ymmärtämisen kannalta tärkeää, että lukija hahmottaa, mikä on tekstin tai lauseen puheenaihe (nimitän sitä ISK:n tapaan teemaksi), miten sitä tekstissä kuljetetaan ja miten uutta eli remaattista tietoa tekstissä annostellaan (vrt. ISK 2004: 1308).

Lauseenjäsenten näkökulmasta lauseen sanajärjestystä ei voi kovin tyhjentävästi lähestyä. ISK:n kenttäkuvaus sen sijaan on melko yksinkertainen tapa kuvata sanajärjestyksen tunnusmerkkisyyttä. Kuten jäljempänä selviää, lausekkeiden sijoittuminen eri kenttiin voi olla tulkinnanvaraista, mutta toisaalta lauseen muiden osien sijoittuminen suhteessa teemaan eli puheenaiheeseen on sen avulla kuitenkin kätevä hahmottaa. E-lauseen tunnusmerkitöntä sanajärjestystä ISK:n kenttäkuvauksessa kuvaa taulukko 1, johon olen lisännyt oikealle puolelle adverbiaalin, verbin ja subjektin keskinäisen järjestyksen. Taulukon lauseet olen poiminut suoraan ISK:sta (mts. 1311, 1314 ja 1316). 
TAULUKко 1. Eksistentiaalilauseiden tunnusmerkitön sanajärjestys ISK:n kenttäkuvauksessa

\begin{tabular}{|c|c|c|c|c|}
\hline \multirow{2}{*}{ avaus } & \multicolumn{2}{|c|}{ alkukenttä } & \multirow{2}{*}{ loppukenttä } & \multirow{2}{*}{ lopetus } \\
\hline & esikenttä & teemapaikka & & \\
\hline & & Pöydällä & $\begin{array}{l}\text { on puhelin ja } \\
\text { paperiröykkiöitä. }\end{array}$ & \\
\hline & & Vaarilla & on puuvene. & \\
\hline & & & Syttyi sota. & \\
\hline
\end{tabular}

Sanajärjestykseltään tunnusmerkittömässä eksistentiaalilauseessa on siis alkukentässä teemapaikalla habitiivinen tai lokatiivinen adverbiaali. Verbialkuinen loppukenttä sisältää myös NP:n, jota ISK:n tapaan nimitän tässä e-subjektiksi (esim. ISK 2004: 1313). Ns. ilmiölauseissa (ks. ISK 2004: 855-856), kuten lauseessa Syttyi sota, teemapaikka on tyhjä.

ISK:n kenttäkuvauksessa puututaan myös lauseen informaatiorakenteeseen ns. temaattisen ja remaattisen osan (eli reeman) käsittein (ISK 2004: 1308-1309). Teemaa ja reemaa en ole taulukkoon 1 erikseen merkinnyt, mutta näissä esimerkeissä lauseen temaattista osaa vastaa alkukenttä, kun taas koko loppukenttä kuuluu remaattiseen osaan. Lauseen temaattinen ja remaattinen osa eivät silti aina käy yksi yhteen alkukentän ja loppukentän kanssa, vaan joskus loppukentästä vain osa voi olla remaattista (ns. suppea reema, ISK 2004: 1308) tai reema olla esikentässäkin (mts. 1320-1321). Reeman sijoittumista esikenttään käsitellään jäljempänä tunnusmerkkisen sanajärjestyksen yhteydessä. Lauseen avaus- ja lopetuskenttiä en tässä yhteydessä analysoi, ja siksi olen poistanut nämä kaksi kenttää jäljempänä olevista taulukoista.

\section{Tilastollisia havaintoja}

Tässä luvussa esitän tilastollisen yleiskatsauksen e-lauseiden sanajärjestyksen variaation kehitykseen taitotasoittain. Kuten edellä taulukossa 1 kuvasin, pidän tunnusmerkittöminä sanajärjestyksiä AVS ja VS, siis niitä e-lauseen tyyppejä, joissa e-subjekti on "normaalilla" paikallaan verbin 
jäljessä, loppukentässä (vrt. ISK 2004: 1313). Tämä järjestys voi varioida usealla eri tavalla, esimerkiksi siten, että teemapaikan edelle esikenttään sijoittuu jokin ilmaus. Variaation taustalla voi olla paitsi temaattisia myös syntaktisia syitä, sillä esimerkiksi kysymyslauseissa ja relatiivilauseissa esikenttä täyttyy kieliopillisin perustein (ISK 2004: 1317). Kuvioissa 1 ja 2 esitellään e-lauseiden sanajärjestyksen variaatiota taitotasoittain aikuisten ja koululaisten kirjoittamissa teksteissä.



Kuvio 1. E-lauseiden sanajärjestyksen variaatio taitotasoittain aikuisten kirjoittamissa teksteissä (\%)

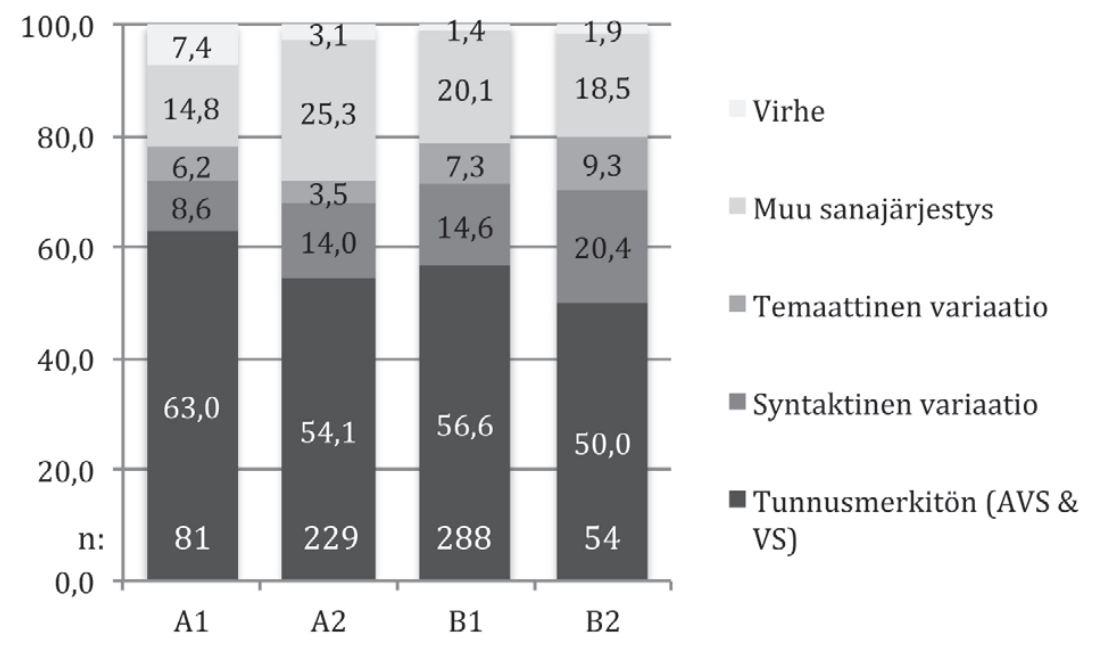

Kuvio 2. E-lauseiden sanajärjestyksen variaatio taitotasoittain koululaisten kirjoittamissa teksteissä (\%) 
Kuvioissa 1 ja 2 jokaisen pylvään alin osa kuvaa tunnusmerkittömien AVS- ja VS-sanajärjestysten osuutta. Syntaktisella ja temaattisella variaatiolla tarkoitetaan näiden kahden sanajärjestyksen muita variantteja. Syntaktinen variaatio käsittää esimerkkien (1-4) kaltaiset e-lauseet, joissa teemapaikan edellä oleva esikenttä täyttyy kieliopillisin perustein, käytännössä relatiivipronominilla (esim. 1), kysymyssanalla (esim. 2) tai kysyvällä verbimuodolla (esim. 3-4). Esikentän ilmaus on alleviivattu, ja lauseen loppuun olen merkinnyt taitotason.

(1) He eivät näe mitä heidän ympärinsä tapahtuu. (B2)

(2) Mitä kokeessa oli? (A2)

(3) Toimiiko minun kotipaikkakunnallani jokin paikallisyhdistys? (C2)

(4) Näkyykö tuloksia? (C1)

Muunlaiset VS- ja AVS-sanajärjestysten variaatiot olen kuviossa alustavasti nimennyt temaattiseksi variaatioksi. Pylvään tässä osassa ovat tarkemmin sanottuna ne VS- ja AVS-sanajärjestysten variaatiot, joille ei ole sellaisia syntaktisia perusteita kuin esimerkeissä (1-4). Taustalla on siis oletus, että mikäli sanajärjestys on neutraalista poikkeava ilman selkeitä syntaktisia perusteita, sillä täytyisi olla tekstiyhteyteen, esimerkiksi teemankuljetukseen (vrt. Shore 2008) liittyvä funktio. Olen siis nimennyt nämä sanajärjestysvariantit alustavasti temaattisiksi, mutta oletuksen vahvistamiseksi lauseita on tarkasteltava tekstiyhteydessään. Näin teenkin seuraavissa alaluvuissa.

Kuvioissa 1 ja 2 tarkoitan ns. muulla sanajärjestyksellä sellaisia e-lauseita, joiden rakenne on monimutkaisempi kuin tunnusmerkittömät AVS ja VS sekä näiden variaatiot. Esimerkkien (5-9) kaltaiset lauseet ovat siis tässä palkissa.

(5) Omalääkärilläni on lounaansa tietokonepöytänsä päällä. (C1)

(6) Etelämaissa perheellä on nykyisinkin suuri rooli omaisten hoidossa. (C1)

(7) [---] koska vaan koulussa on luokassa paljon opilaita [---] (B1)

(8) Nyt sitä ei minulla ole liittää hakemukseeni ensi maaliskuussa. (C2)

(9) Meillä on pitkään ollut käsitys, että [---] (C1)

Kuten esimerkeistä (5-9) huomaa, aineistossa on erityisesti ylemmillä tasoilla lauseita, joiden sanajärjestys on (A)VS-järjestystä ja sen 
variaatioita monimutkaisempi. Tällaisissa lauseissa on esimerkiksi useampia adverbiaaleja, partikkeleita tai sellaisia verbin kielto- ja liittomuotoja, joiden osat ovat toisistaan erillään. Esimerkkien (5) ja (6) kaltaiset lauseet, joissa on sekä habitiivinen että lokatiivinen adverbiaali, eivät ole kenttäkuvauksen kannalta kovinkaan ongelmallisia. Esimerkissä (5) habitiiviadverbiaali omalääkärilläni täyttää teemapaikan ja lauseen verbialkuinen loppuosa täyttää koko loppukentän. Sen sijaan ei ole aivan yksiselitteistä, kumpi esimerkin (6) adverbiaaleista, etelämaissa vai perheellä, lopulta olisi ensisijaisempi teema. Loogiselta vaikuttaisi, että se olisi habitiivinen perheellä, jolloin paikanilmaus etelämaissa olisi esikenttään sijoittuva puiteadverbiaali, ja esikenttään sijoittuva ilmaus saa aikaan kontrastiivisen vaikutelman etelämaiden ja muiden maiden välille (vrt. ISK 2004: 1319). Oman tarkastelunsa vaatisivat myös rektioadverbiaalin asema lauseessa (esim. 6 rooli omaisten hoidossa), partikkeleiden sijoittuminen (vrt. Toikka 2012), kahden paikanilmauksen keskinäinen järjestys (esim. 7) sekä ajanilmauksen paikka (nyt ja ensi maaliskuussa esimerkissä 8). Aineistossa esiintyy myös sellaisia verbin liitto- ja kieltomuotoja, joiden osien välissä on muita elementtejä (esim. ei minulla ole esimerkissä 8 sekä on pitkään ollut esimerkissä 9). Kaikki tällaiset perustyyppiä (A)VS monimutkaisemmat sanajärjestykset olen sijoittanut kuvioissa 1 ja 2 kohtaan muu sanajärjestys. Se ei tietenkään tarkoita, ettei näilläkin sanajärjestysvarianteilla voisi olla temaattisia tai syntaktisia perusteita.

Kuvioiden 1 ja 2 pylväissä ovat ylimpänä virheellisiksi merkityt lauseet. Tähän kohtaan olen luokitellut esimerkkien (10-14) kaltaisia lauseita.

(10) Lähikaupassa tuore ruokia. (A1)

(11) Museossa ihan monta esinettä. (A2)

(12) Tarkeempi on että opetajat ja vänhemätlla hyvää yhteistyö (B2)

(13) Se tulee paljon autoa (A2)

(14) Se oli niin paljon gramatiikka kursilla! (A2)

Sen määrittäminen, mikä sanajärjestys on virheellinen, voi olla hankalaa, vaikka lauseita tarkastelisi tekstiyhteydessäänkin. Tässä vaiheessa olen 
rajannut sanajärjestykseltään virheellisten luokkaan ensinnäkin sellaiset lauseet, jotka ovat vajaita mutta eivät elliptisiä. Pääosin kyse on lauseista, joista puuttuu verbi ja joissa adverbiaalin, verbin ja e-subjektin keskinäistä järjestystä ei siten voi yksiselitteisesti määrittää (esim. 10-12). Varsinaisesti lauseissa (10-12) ei ole kysymys sanajärjestysvirheestä järjestyshän on muuten oikea, verbi vain puuttuu. Virheellisiksi olen laskenut myös esimerkkien (13) ja (14) kaltaiset lauseet, koska pronominin se kaltainen muodollinen subjekti ei kuulu suomen eksistentiaalilauseeseen. Esimerkissä (13) pronomini saattaisi viitata paikkaankin (vrt. esim. Sieltä tulee paljon autoja), kun taas esimerkistä (14) näkyy selvästi, kuinka pronomini se on lauseessa muodollisen subjektin tehtävässä. On toki olemassa lauseita, joissa teemapaikalle sijoittuu ns. paikanpitäjä. Tällöin teemapaikalla oleva paikanpitäjä osoittaa edeltävän ilmauksen esikenttään kuuluvaksi ja tekee sanajärjestyksestä tunnusmerkkisen (esim. On sitä niin monenlaista tyyliä näissäkin hommissa, ISK 2004: 1321). Tästä ei kuitenkaan ole esimerkkien (13) ja (14) lauseissa kysymys, varsinkaan kun esikentässä ei ole näissä lauseissa mitään.

Kuvioista 1 ja 2 voi päätellä, että yksinkertaiset, tunnusmerkittömät AVS- ja VS-muotoiset e-lauseet ovat selvästi yleisin e-lauseen tyyppi kaikilla kirjoitustaidon tasoilla kummassakin aineistossa. Tämäntyyppisten e-lauseiden sekä temaattisesti että syntaktisesti motivoitu variaatio lisääntyy taitotason noustessa. AVS- ja VS-tyyppeihin luokitellut e-lauseet variaatioineen kattavat yhdessä n. 80 \% kaikista e-lauseista aikuisten kirjoittajien teksteissä, ja lähes samalla tasolla näiden lauseiden osuus on myös koululaisten kirjoittamissa teksteissä.

Syntaktisesti motivoidun variaation suurta osuutta koululaisteksteissä selittää suurelta osin tehtävänanto, joka ohjasi kysymään opettajalta läksyjä ja kaikkea muutakin, mitä koulussa on tapahtunut oppilaan poissa ollessa. Näissä koululaisten teksteissä on runsaasti kysymyslauseita, joiden esikenttäalkuinen sanajärjestys on siis syntaktisesti motivoitu.

Variaation lisääntymisestä kertoo kuvioissa myös muiden, monimutkaisempien e-lauserakenteiden kasvava osuus, joka on suurempi 
koululaisten teksteissä. Siitä huolimatta, että e-lauseiden sanajärjestyksen variaatio on koululaisten teksteissä runsaampaa, virheiden osuus on niissä pienempi kuin aikuisten teksteissä vastaavalla taitotasolla.

Koululaisten kyky tuottaa virheettömämpää kieltä on havaittu myös aiemmin tutkittaessa eksistentiaalilauseen (Kajander 2013) ja impersonaalisten rakenteiden (Seilonen 2013) muotopiirteitä. Lisäksi havaittiin, että myös verbivalikoima laajenee näissä rakenteissa koululaisilla varhemmin kuin aikuisilla. Aikuisten vahvuudet taas liittyvät ennemminkin em. rakenteiden abstraktimpiin käyttöihin. (Tarkemmin: Kajander 2013: 212-213; Seilonen 2013: 188-190.)

Edellä kuvaamani ryhmittely tuo esille vasta suuntaa antavan yleiskuvan e-lauseiden sanajärjestyksen variaation kehityksestä. Tunnusmerkittömät sanajärjestystyypit AVS ja VS ovat siis aineistossa yleisimpiä, mutta toisaalta niiden variantteja ja sanajärjestykseltään vielä monimutkaisempiakin rakenteita on lukuisia erilaisia, joten yksittäisten tunnusmerkkisten sanajärjestysvarianttien määrät jäävät hyvin pieniksi. Tilastollisin menetelmin voi kuitenkin osoittaa, että e-lauseiden sanajärjestyksen variaatio lisääntyy aikuisten kirjoittamissa teksteissä (kuvio 1) sekä tasolle B että tasolle C siirryttäessä: ero A- ja B-tasojen välillä on tilastollisesti erittäin merkitsevä (tasot $\mathrm{A} 1+\mathrm{A} 2$ vs. tasot $\mathrm{B} 1+\mathrm{B} 2: \chi^{2}=22,27$; $\mathrm{df}=4 ; \mathrm{p}<0,001)$ ja samoin tasojen $\mathrm{B}$ ja $\mathrm{C}$ välillä (tasot $\mathrm{B} 1+\mathrm{B} 2$ vs. tasot $\mathrm{C} 1+\mathrm{C} 2: \chi^{2}=22,01 ; \mathrm{df}=4 ; \mathrm{p}<0,001$ ). Koululaisten aineistossa (kuvio 2) erot taitotasojen välillä eivät sen sijaan ole tilastollisesti merkitseviä. Kouluaineistossa tilastollisesti merkitsevien erojen löytämistä hankaloittaa myös se, että tasoilla A1 ja B2 e-lauseita on muutenkin vähän.

(A)VS-sanajärjestystyypin temaattisiksi luokittelemiani variaatioita on aikuisten teksteissä kaikkiaan 106 kappaletta. Näistä 58 kappaletta (n. 55 \%) on muotoa SVA tai SV. Koululaisten teksteissä, joita tosin on sanemäärältäänkin vähemmän, temaattisiksi luokiteltuja (A)VS-tyypin variaatioita on 39 kappaletta. Näistä tyyppiä SVA tai SV on 21 kappaletta (n. $54 \%$ ). Lukumäärät ovat tietenkin hyvin pieniä, kun ottaa huomioon, että e-lauseita on aikuisten aineistossa yhteensä 909 kappaletta ja kouluaineistossakin 652 kappaletta. Sanajärjestys, jossa on verbinetinen 
e-subjekti, on silti kuitenkin yleisin niistä e-lauseen varianteista, joilla oletan olevan temaattisia tehtäviä.

Tarkastelen seuraavaksi muutamia SV-järjestyksisiä e-lauseita tekstiyhteydessään. Pohdin niiden käyttöä myös informaatiorakenteen kannalta sekä esikenttäalkuisesta sanajärjestyksestä implikoituvia lisämerkityksiä. Lopuksi käsittelen verbinetisen e-subjektin temaattista ja vakiintunutta käyttöä.

\section{E-subjekti esikentässä: vakuutteleva sävy}

Eksistentiaalilauseen yksinkertaisin alatyyppi on ns. ilmiölause (esim. Syttyi sota.). Ilmiölause on tyypillisesti verbialkuinen ja usein pitkälle kiteytynyt. Vaikka ilmiölauseessa ei olekaan lokatiivista adverbiaalia, se tulkitaan usein tekstissä mainittua tai siitä pääteltävissä olevaa paikkaa koskevaksi. Sanajärjestys voi olla myös NP-alkuinen. (ISK 2004: 855-856.)

Tarkastelen aluksi yksinkertaisia ilmiölauseita, joissa e-subjekti esiintyy verbin edellä. Syntaktisten roolien kannalta näiden lauseiden rakenne on SV; niissä on siis e-subjekti, jota seuraa lauseen predikaattiverbi. ISK:n kenttäkuvauksessa verbialkuisen ilmiölauseen teemapaikka on tyhjä, ja siten koko lause sijoittuu kenttäkuvauksessa loppukenttään (vrt. taulukko 1). Mutta entä jos järjestys onkin käänteinen, e-subjektilla alkava? Voiko verbiä edeltävä e-subjekti silloin sijoittua teemapaikalle tai esikenttään?

ISK:n kenttäkuvauksessa kaikki kentät eivät ole lauseessa välttämättömiä; lause voi koostua pelkästä loppukentästäkin, kuten VS-tyyppinen ilmiölause. Toisaalta mainitaan myös, että alkukenttä on kaksijäseninen (eli sisältää sekä esikentän että teemapaikan) silloin, kun esikenttä on täytetty. (ISK 2004: 1307.) Jos siis esikenttä ei täyty ilman teemapaikkaa, tämä tarkoittaisi, että verbinetinen e-subjekti sijoittuisi SV-tyyppisessä ilmiölauseessa automaattisesti kenttäkuvauksen teemapaikalle.

ISK (2004: 1316) pitää ainakin VS-muotoista ilmiölausetta kuitenkin teemattomana, joten ei olisi loogista sijoittaa e-subjektia lauseen teemaksi myöskään siinä tapauksessa, että subjekti edeltää verbiä. Tällöin 
e-subjektin voisi ymmärtääkseni sijoittaa esikenttään siitäkin huolimatta, että teemapaikka on tyhjä. Se, että teemapaikka on tyhjä, ei missään nimessä automaattisesti tarkoita, että lause olisi teematon. Toisaalla ISK (2004: 855-856) nimittäin mainitsee selvästi, että vaikka paikanilmausta ei ole, ilmiölause tulkitaan useimmiten tekstissä mainittua tai siitä pääteltävissä olevaa paikkaa koskevaksi myös NP-alkuisissa ilmiölauseissa. Nähdäkseni tämä aiemmin mainittu tai pääteltävissä oleva paikka voi aivan hyvin ikään kuin täyttää ilmiölauseen teemapaikan. Myös Shore (2008: 52) huomauttaa ilmiölauseiden elliptisyydestä: ilmiölausekaan ei esiinny tyhïiössä, vaan sen temporaaliset tai spatiaaliset puitteet on esitelty edeltävässä tekstissä. Vilkuna (1989: 167) puolestaan korostaa ilmiölauseen temporaalista kehystä. Näillä perusteilla ilmiölauseen tyhjää teemapaikkaa voisi pitää kontekstista tai muuten pääteltävissä olevalle teemalle varattuna, jolloin käänteisessä järjestyksessä e-subjekti sijoittuisi ongelmitta esikenttään, kuten taulukossa 2 esitän. Taulukon esimerkkilauseet ovat Cefling-aineiston teksteistä, ja taitotaso on merkitty sulkeisiin lauseen jälkeen.

TAULUKко 2. VS- ja SV-järjestyksiset ilmiölauseet kenttäkuvauksessa

\begin{tabular}{|l|l|l|}
\hline \multicolumn{2}{|c|}{ alkukenttä } & \multirow{2}{*}{ loppukenttä } \\
\hline \multicolumn{1}{|c|}{ esikenttä } & teemapaikka & \multicolumn{1}{|c|}{ Tuli tärkeä työjuttu. (A2) } \\
\hline rostetta ('ruostetta') & & ei ole (A2) \\
\hline vikoja & & löytyy (C1) \\
\hline
\end{tabular}

ISK:n (2004: 1320-1321) mukaan reeman eli lauseen pääuutisen sijoittuminen esikenttään on tunnusmerkkistä, ja varsinkin subjektin sijoittuessa esikenttään tätä tulkintaa tukevat lauseen verbiloppuisuus sekä subjektin ja verbin väliin sijoittuva jatkuva teema. Kun teema on jatkuva, tekstissä kuljetetaan samaa puheenalaista diskurssireferenttiä teemapaikassa, tosin saman tarkoitteen uudelleenmaininnat voivat sijoittua lauseissa muihinkin asemiin kuin teemaksi (ISK 2004: 1309). Taulukossa 2 olen sijoittanut verbinetisen e-subjektin esikenttään enkä teemapaikalle, 
sillä nähdäkseni myös verbinetisessä asemassa e-subjekti voi olla remaattinen. Mikäli e-subjektin katsoo sijoittuvan esikenttään, edeltävästä tekstistä olisi lisäksi löydettävä teemapaikalle sopiva jatkuva teema.

Kun tarkastellaan taulukon 2 lauseita kontekstissaan, tulkinta teeman jatkuvuudesta ja esikenttään sijoittuvasta reemasta saa vahvistusta. Olen lisännyt esimerkkien (15) ja (16) ilmiölauseisiin hakasulkeisiin mahdollisen jatkuvan teeman, johon viittaavat ilmaukset olen alleviivannut edeltävässä tekstissä. SV-lauseessa remaattiseksi tulkittu e-subjekti on lihavoitu.

(15) Nelja vuotta sitten ostin ensimmäisen "aidon" auton (ennen sitä olen vaihtanut monta Ladaa). Se oli Ford Focus, joka valittiin "vuoden autoksi” sekä Euroopassa ja USA:ssa. Se tietenkin vaikutti päätökseeni ostamaan juuri tämän mallin.

Jos minulta nyt kysytään, olenko autooni tyytyväinen, vastaan aina "kyllä". Auto täytti odotukseni. Sillä on erinomainen ajettavuus. Se on kaunis. Ja hinta/laatusuhde on kohdallaan.

Olen lukenut jostain, että Saksan autokatsastustilastossa Focus ja C-Max ovat saaneet miltei täydet arvosanat. Siitä huolimatta, vikoja [Fordista] löytyy, niin kuin jokaisesta autosta, olipa se Ford vai Jaguar. (C1)

(16) Minä haluan myydä auto Opel Kadet Farmari 1993 v. 1400 motorri, 5 ovea., 4 kessä rengasta mukana. Autokatsostus olli 19.12.04, rostetta [autossa] ei ole, siisti. Jos Te haluatte ostaa, pyydää soitta puhelemineen [---] (A2)

Kummassakin esimerkissä referentti auto tuodaan tekstiin ensimmäisessä virkkeessä. Esimerkissä (15) autoon viitataan myöhemmin myös pronominein sekä mainitaan lisäksi auton merkki. Vaikka kirjoittajan autoon viittaavat ilmaukset eivät edeltävissä lauseissa aina kuljekaan teemapaikalla, siitä huolimatta on aivan selvää, että lauseessa vikoja löytyy teemana on kirjoittajan Ford Focus -merkkinen auto, vaikka teema ei olekaan lauseessa ilmipantuna. (Huomaa, että myös ensimmäisen kappaleen lopussa mainittu hinta-laatu-suhde koskee samoin juuri kirjoittajan omaa automallia, vaikkei sitä lauseessa mainitakaan.) 
Esimerkin (16) tekstissä kirjoittajan auto merkkeineen mainitaan vain alussa, minkä jälkeen auton ominaisuudet luetellaan. Tämä onkin lyhyessä ilmoitusmuotoisessa tekstissä luonnollista. Teemaa uudelleen mainitsemattakin on selvää, että moottorin tilavuus, vuosimalli sekä muut luetellut asiat koskevat myytävää autoa, mikä osaltaan ohjaa ajattelemaan myös jäljempänä tulevan ilmiölauseen teemaksi kyseisen auton. Varmasti myös maailmantieto auttaa siinä, ettei ilmiölauseen teemaksi (eli käytännössä ruosteen sijaintipaikaksi) käsitetä juuri edellä mainittuja autokatsastusta eikä kesärenkaita.

Reema-alkuiset lauseet toimivat vahvistuksina, oikaisuina, vastaväitteinä tai vakuutteluna (ISK 2004: 1320-1323). Tämä tulkinta sopii hyvin myös esimerkkien (15) ja (16) lauseisiin. Esimerkissä (15) auton viat ovat selvästi lauseen uutisarvoisin asia, varsinkin kun edellä on esitelty ainoastaan auton hyviä puolia. Sijoittamalla reeman esikenttään kirjoittaja ilmaisee käsityksensä eroavan siitä, mitä taustaksi esitetään (vrt. ISK 2004: 1322). Samoin esimerkissä (16) ruoste mainitaan selvästi lauseen pääuutisena, ja sen sijoittaminen esikenttään tuo lauseeseen vakuuttelevan sävyn, jota tunnusmerkitön sanajärjestys ei välttämättä toisi (vrt. esim. Autossa ei ole ruostetta.).

\section{Modaalinen partikkeli esikentässä: kontrastiivinen tulkinta ja teeman vaihtuvuus}

Kun esikenttään sijoittuu modaalinen partikkeli (esim. kyllä, kai, toki, tuskin), lause koskee ensisijaisesti polaarisuutta eli sitä, pitääkö ilmaistu asiaintila paikkansa vai ei. Modaalinen partikkeli sijoittuu tällaisissa lauseissa välittömästi teeman edelle, teema on jatkuva ja lause usein verbiloppuinen. (ISK 2004: 1323-1324.) Mutta kuinka modaalisella partikkelilla alkava, pSV-järjestyksinen ilmiölause pitäisi kenttäkuvaukseen sijoittaa? Havainnollistan asiaa taulukossa 3, jonka ensimmäisen lauseen olen poiminut ISK:sta. Aineistosta poimittuihin lauseisiin on merkitty taitotaso, ja kokonaan sulkeissa olevan lauseen olen kehittänyt itse. 
TAULUKко 3. Modaalisella partikkelilla alkava e-lause ISK:n kenttäkuvauksessa

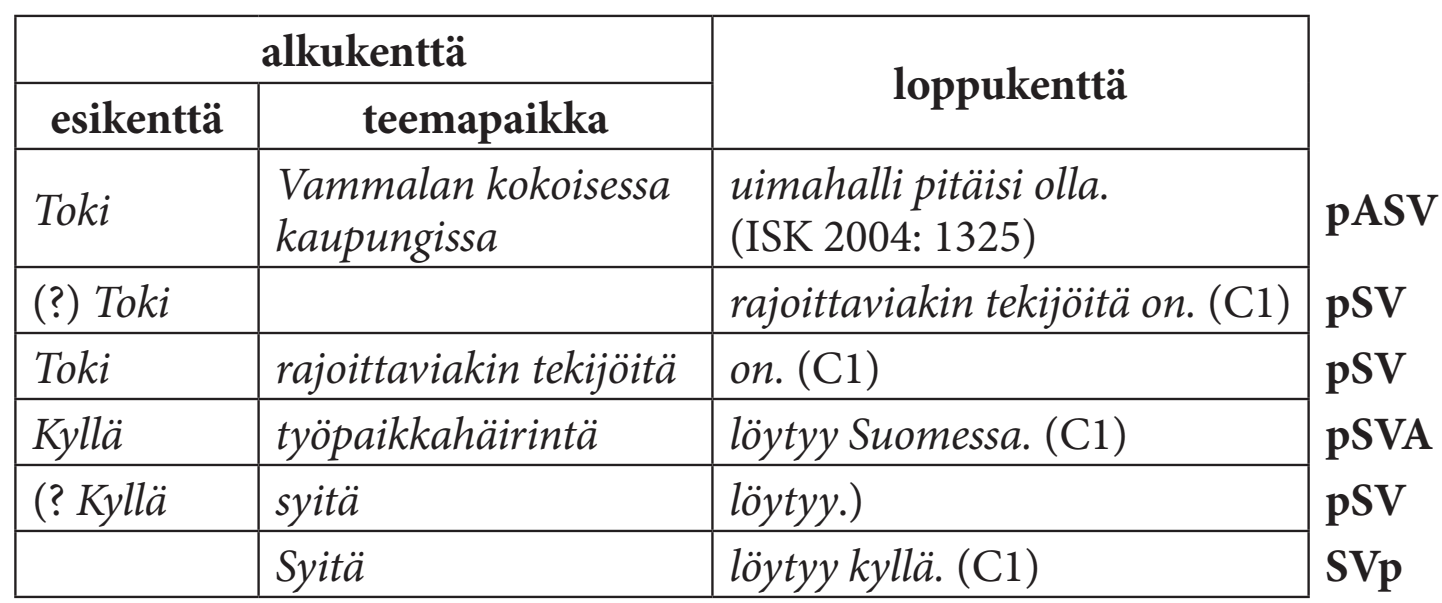

Taulukon 3 ensimmäisessä lauseessa teemapaikka on täytetty, ja jos partikkeli toki sijoittuu välittömästi teeman edelle esikenttään, e-subjektin ja verbin paikaksi jää loppukenttä. Edellä (vrt. taulukko 2 ja esimerkit 15 ja 16) esitin, että myös ilmiölauseen teema on jatkuva, ja siten myös lause Toki rajoittaviakin tekijöitä on sijoittuisi kenttäkuvaukseen niin, että teemapaikka jäisi tyhjäksi eli varatuksi tekstiyhteydestä pääteltävissä olevalle jatkuvalle teemalle. Lause sijoittuisi tässä tapauksessa partikkelia lukuun ottamatta loppukenttään (vrt. taulukon 3 toinen lause).

Ilmiölauseen teemapaikan varaaminen pelkästään pääteltävissä olevalle teemalle ei kuitenkaan välttämättä ole tarpeellista. Jäljempänä olevista tekstiesimerkeistä selviää, että teemapaikalle voisi perustellusti sijoittaa e-subjektinkin (vrt. ISK 2004: 1312 esimerkki: Vastuu nuorista on meillä kaikilla.). Tätä tulkintaa puoltaa mielestäni myös partikkelin sijoittuminen esikenttään.

E-subjektin ja partikkelin asemaan kenttäkuvauksessa voi kuitenkin ottaa kantaa vain tarkastelemalla lauseita tekstiyhteydessään (esim. 17 ja 18). Olen jälleen lisännyt hakasulkeisiin jatkuvan teeman, alleviivannut siihen viittaavat edeltävät ilmaukset ja lihavoinut verbiä edeltävän e-subjektin. 
(17) Kaupunkiloma vai luontokohde

Loman suunnittelussa on hyvää tietää, että lomanviettoa ja aikatauluja voi molemman vaihtoehdon kohdalla suunnitella aika vapaasti. Toki rajoittaviakin tekijöitä [molemmissa vaihtoehdoissa] on. Kaupunkiloman aktiviteettien aikataulun määrittelevät pääsääntöisesti museoiden, näyttelyiden ja liikenteen aikataulut. Aluekin on rajatumpi, mutta toisaalta kaikki on kompaktisti ns. käden ulottuvilla. Kaupunkiloman onnistumiseen ei vaikuta sää ja vuodenaika niin olennaisesti, kuin luontokohteeseen matkustamalla. Luontokohde on siina mielessä riippuvaisempi ulkoisista tekijöistä. (C1)

(18) Mielipidekirjoitus Solkilan Sanomanlehteen. Onko työpaikkahäirintä ongelma Suomessa?

Ihana kesäkuun varhaisaamu, ilma on lämmin ja raikasta, linnut laulavat. Ensimmäinen työpäivä ja hetkessä se onkin ohi. Sitten viikko ja kuukausi. Pikkuhilja tulee työelämään epämukavia hetkiä, epävarmuutta, epäystävällisyyttä, epätyytyväisyyttä, epäluotettavuutta jne. Epä! Ja sitten se selviäkin - olen maahanmuuttaja! Syitä [työpaikkahäirintään] löytyy kyllä, puhut korostuksella kieltä, miksi tulit? Oletko kunnollinen ihminen, oletko terve, tehdäänkö teidän kotimaassa rokotuksia ollenhgaa? Tulitko ottamaan työpaikan suomalaiselta työntekijältä?

Onko mahdollista olla hyvä ja tunnollinen työntekijä jos työilmapiiri on lannistava ja epäposittiivinen. Vastaus on Kyllä on mahdollista olla hyvä ja arvostetty työntekijä olemalla posittiivinen, itsevarma, ystävällinen, tyytyväinen ja tekemallä ahkerasti töitä. Aina on myös mahdollista edistyä suomen kielen osaamisessa. Maailma on töynnä erilaisia ihmisiä, tarjolla erilaisia työpaikkoja. Kysymys on, että minkälainen ihminen olet itse ja teetkö mahdolliseksi häiritä itseä työpaikalla tai keskittyt tärkeimpään - työntekoon? Kyllä työpaikkahäirintä löytyy Suomessa jos haluat sitä löytää mutta se riippuu sinusta että haluatko? (C1)

ISK (2004: 1526) pitää alkuasemaista kyllä-partikkelia tyypillisenä reaktiivisissa lauseissa, kun taas loppuasemainen kyllä on mahdollinen keskustelussa lausuman lopussa. Kuten taulukon 3 viimeisestä lauseesta ja esimerkistä (18) näkyy, partikkeli kyllä voi olla myös lauseen lopussa. Tekstiyhteyteensä esimerkin (18) kyllä-loppuinen lause sopii mielestäni 
hieman luontevammin kuin kyllä-alkuinen variantti samasta lauseesta (sulkeissa taulukossa 3). Luultavasti tämä johtuu siitä, että kyllä-alkuinen lause olisi reaktiivisempi, mutta kovin suurta vivahde-eroa partikkelin alku- tai loppuasemaisuus ei lauseeseen tuo.

Viimeisen kappaleen kaksinkertaisesti alleviivatussa lauseessa alkuasemaisen partikkelin käyttö on perustellumpaa. Tekstissä on edellä ja otsikossa esitetty useita kysymyksiä, joten reaktiivinen lause sopii tekstiyhteyteen hyvin, vaikka se ei itse asiassa toimikaan vastauksena näihin kysymyksiin. Kaksoisalleviivatun lauseen sanajärjestyksessä huomiota herättää se, että paikanilmaus Suomessa on lopussa eikä esim. teemapaikalla. Vaikka teemapaikalla olisi e-subjektikin, verbiloppuinen järjestys olisi silti luontevampi (vrt. Kyllä Suomessa työpaikkahäirintää löytyy tai Kyllä työpaikkahäirintää Suomessa löytyy).

Esimerkeissä (17) ja (18) ilmiölauseen teeman voi päätellä edellä olevasta tekstistä niin yksiselitteisesti, ettei sen maininta ilmiölauseessa ole enää välttämätöntä oikean tulkinnan kannalta. Kummassakin tekstissä on kyse jo otsikossa mainitusta teemasta, siis tekstin pääteemasta, jota koko teksti jo otsikon perusteella ilman muuta käsittelee.

Shore (2008) kiinnittää huomiota siihen, että teemoja voi olla useitakin. Lauseessa teeman lisäksi esiintyvät muut verbinetiset konstituentit voivat hänen mukaansa toimia ns. orientoivina sivuteemoina. Tällainen orientoiva sivuteema voi olla myös verbin pakollinen argumentti (Shore 2008: 44-49), siis mahdollisesti e-subjektikin. Molemmissa esimerkkien (17) ja (18) ilmiölauseissa lihavoitu ilmaus on uutta informaatiota, joka otetaan tekstissä ensimmäistä kertaa esille: syihin tai rajoittaviin tekijöihin ei ole aiemmin viitattu. Lauseen teemapaikka on tyhjä (vrt. taulukko 3), mutta teemaksi ymmärretään otsikossakin mainitut lomavaihtoehdot (teksti 17) tai työpaikkahäirintä (teksti 18), joihin useasti viitataan jo ennen tunnusmerkkistä ilmiölausetta. Lihavoitua e-subjektia voi siis kummassakin lauseessa hyvin perustein pitää lauseen esikentässä olevana reemana.

Silmiinpistävää kummassakin tekstissä kuitenkin on, että ilmiölausetta seuraa välittömästi luettelo: loman rajoittavia tekijöitä ja 
työpaikkahäirinnän syitä luetellaan useita. Sekä syyt että rajoittavat tekijät ovatkin yhtäkkiä uusi teema, jota käsitellään seuraavaksi yksityiskohtaisemmin. Shoren (2008: 44-49) käyttämässä terminologiassa lihavoitu ilmaus olisi orientoiva sivuteema, josta voi syntyä kontrastiivinen tulkinta eli implikaatio siitä, että lause kertoo jostakin asiakokonaisuudesta vain osan (vrt. ISK 2004: 1318). ISK:n näkökulmasta kyseessä olisi ns. vaihtuva teema (mts. 1309), joka sekin luo kontrastiivisen tulkinnan.

Kontrastiivinen tulkinta on perusteltu, kun katsotaan tekstejä tarkemmin. Esimerkissä (17) mainitaan ensin hyvinä puolina lomailun ja aikataulujen suunnittelun vapaus, minkä jälkeen eritellään sekä kaupunki- että luontoloman rajoittavia tekijöitä. Työpaikkahäirintää koskevassa kirjoituksessa (esim. 18) käy vasta lopussa selväksi, mihin syitä kontrastoidaan: syitä työpaikkahäirintään on, mutta itse häirintää ei, ellei anna sen tapahtua. Kummassakin esimerkkilauseessa on siis selvästi implikaatio, että lause ei ilmaise puheena olevasta asiakokonaisuudesta kuin osan, ja lukijalle syntyy samalla kuva, että tekstin varsinaista, otsikossakin mainittua pääteemaa käsitellään jäljempänä myös toiselta kannalta.

\section{Tunnusmerkitön ja vakiintunut SV-järjestys}

Vaikka VS-järjestystä voikin pitää e-lauseissa tunnusmerkittömänä, ei SV-järjestys silti välttämättä ole kaikissa tapauksissa tunnusmerkkinen. On verbejä, joiden yhteydessä SV-järjestystä voisi pitää vakiintuneena, ja toisinaan verbinetinen e-subjekti saattaakin sopia paremmin lauseen teemapaikalle kuin tunnusmerkkisesti esikenttään. Esimerkissä (19) e-subjekti on lihavoitu, mutta sen remaattisuus on kyseenalaista.

(19) Olen opettanut japania suomalaisille aikuisille yli kymmenen vuotta. Japanin kielen tarve ja suosio ovat kasvanneet ja tällä hetkellä japanin kielen opettajia on yli 50 helsingissä. Töitä [Helsingissä? minulla? japanin kielen opettajilla?] riittää, mutta on myös haasteita. Esimerkiksi joukossa on myös paljon koulutettomia opettajia, jotka näkevät suurta vaivaa opetuksessa. On järjestettävä koulutus mahdollisimman pian, mutta rahoitus puuttuu. (C1) 
Myös esimerkistä (19) käy hyvin ilmi kontrastiivinen tulkinta, josta oli puhetta jo edellä: Töitä riittää, mutta on myös haasteita. Tekstin teemana on japanin kielen opetus, josta kirjoittaja aikoo pitää esitelmän seminaarissa. Hän kuvailee aihetta sähköpostissa seminaarin järjestäjälle. Ensin kuvataan japanin opetuksen hyvää tilannetta, mutta sitten SV-muotoinen lause tuo tekstiin implikaation, että puheena olevasta asiasta ei olekaan vielä sanottu kaikkea. Seuraavaksi paneudutaankin ongelmakohtiin. Verbialkuinen on myös haasteita on järjestykseltään tunnusmerkitön, mutta silti se toimii johdantona luetteloon, aivan kuten SV-järjestyksiset e-lauseet esimerkeissä (17) ja (18).

Ilmiölauseen jatkuva teema ei ole esimerkissä (19) aivan yksiselitteinen. Vaikka tekstin aiheena on japanin kielen opetus, työn paljous ja haasteet koskevat paremminkin joko kirjoittajaa itseään, koko opettajakuntaa tai sitten vain Helsinkiä paikkana. Toinen silmiinpistävä ero edellisiin esimerkkeihin verrattuna liittyy lihavoituun verbinetiseen e-subjektiin. Esimerkeissä (17) ja (18) verbinetinen e-subjekti on selvästi ennen mainitsematon ja sitä seuraa luettelo. Esimerkissä (19) tilanne on päinvastainen. Edeltävässä tekstissä kuvaillaan työtä ja sen runsautta viitaten niin oppilaiden kuin työkavereidenkin määrään. Lisäksi työn mainitaan myös jatkuneen pitkään. Seuraavan e-lauseen ilmaus töitä siis kokoaa edellä käsiteltyä aihetta eikä siten anna uutta tietoa.

Verbiloppuista lausetta Töitä riittää voisi hyvin pitää sanajärjestykseltään vakiintuneenakin (vrt. ?Riittää töitä.). Varsinkaan, kun lauseessa ei ole ilmipantua teemaksi sopivaa adverbiaalia (Minulla riittää töitä.) ja kun subjektia ei oikein voi tulkita esikentässä olevaksi reemaksi, on luontevampaa tulkita e-subjektin täyttävän lauseen teemapaikan. Aineistosta löytyy myös toinen vastaavanlainen esimerkki (20), jossa esikentän e-subjektilla on samanlainen edellä sanottua kokoava tai toistava tehtävä. Kontrastiivinen tulkinta voisi lauseesta kyllä seurata, kuten esimerkissä (19), mutta esimerkin (20) kirjoittaja ei kuitenkaan jäljempänä tulevassa tekstissä kontrastoi vaan siirtyy kertomaan esitelmänsä aiheesta. 
(20) Osallistun hoitopedagogiseen seminaariin ilomielin. Olen työssä erityistä huolenpitoa tarvitsevien lasten ja nuorten yhteisössä ja minulla on paljon työkokemuksia ja kerrottavaa ja myös kysyttävää. Tärkeimmät tehtävät yhteisössämme ovat lasten ja nuorten hoito ja ohjaus päivittäisessä elämässä, vuorovaikutus lasten ja nuorten vanhempien ja sosiaaliviranomaisten kanssa. Me teemme yhteistyötä myös lääkäreiden kanssa. Eli - työtä ja tehtäviä ja siihen liittyviä kysymyksiä riittää.

Esitelmäni teemana siis olisi - talon (yhteisön) emännän ja kotiapulaisten rooli [---] (C2)

Subjektialkuinen sanajärjestys vaikuttaa aineistossa lisäksi yleiseltä etenkin verbien riittää, sattuu, ilmenee ja löytyy yhteydessä sivulauseessa (esim. 21-26). SV-sanajärjestystä esiintyy myös päälauseessa silloin, kun sitä edeltää jos-sivulause (esim. 27 ja 28). Verbiä edeltävä e-subjekti on esimerkeissä lihavoitu.

(21) Talkoot alkavat klo. 10 ja kestävät niin kauan kun innostusta ja energiaa riitaa! ( $\mathrm{C} 1)$

(22) Ja paikalla olevat pääsevät varmasti mukaan, muut vain jos paikkoja riittää. (C2)

(23) Täytyy maksaa kallista bensiiniä ja paljon veroja, sekä korjauksia jos jotain sattuu. (B2)

(24) Epäkohtiin on puututtava ajoissa ja muutoksia on tehtävä jos puutteita ilmenee. (C2)

(25) Jos rakennus ei täytä tiettyjä vaatimuksia ja virheitä löytyy, ne on korjattava. (C2)

(26) mutta jos niitä ei ole tule kuitenkin (C2)

(27) Ja jos pitää lähteä johonkin uuteen paikkaan (kylään tai kaupunkiin), niin omaa asuntoakaan ei ole. (C1)

(28) Jos kaikki ihmiset sopisivat samaan standardiin, lihavuusongelmaa ei olisi ja moni terveysriski jäisi pois. (C2)

Edellä olevien esimerkkien perusteella on mahdollista, että SV-järjestys on joidenkin verbien yhteydessä vakiintuneempaa ja siten ehkä vähemmän tunnusmerkkistä. Alisteisissa lauseissa verbiloppuisuus ei välttämättä ole tunnusmerkkistä (ISK 2004: 1329-1331), mutta e-subjektin asemaa tällaisissa lauseissa kannattaisi silti tutkia lähemmin. On 
huomattava, että VS-järjestyskin olisi ainakin yllä olevien esimerkkien sivulauseissa mahdollinen (esim. jos ilmenee puutteita, jos löytyy virheitä, ei olisi lihavuusongelmaa). Se, onko ilmiölauseen SV-järjestys tunnusmerkkisempi tai vakiintuneempi näissä tapauksissa, vaatisi lauseiden tutkimista laajemmassa tekstiyhteydessään ja laajemmasta aineistosta.

\section{Päätelmiä}

Olen tässä artikkelissa havainnollistanut e-lauseiden tunnusmerkkisten sanajärjestysvarianttien esiintymistä ja käyttöä suomenoppijoiden teksteissä. Tilastollinen tarkastelu antaa alustavan kuvan siitä, kuinka sanajärjestyksen variaatio lisääntyy ainakin eksistentiaalisissa lauseissa kirjoitustaidon tason kasvaessa. On selvää, että sanajärjestyksen variaation kehityksestä saisi paremman kokonaiskuvan, jos huomioitaisiin myös muut lausetyypit. Erilaisten sanajärjestysvaihtoehtojen käytön tarkastelu taas vaatii ilman muuta lauseiden tutkimista tekstiyhteydessään.

Edellä on käsitelty useita tekstiesimerkkejä, jotka osoittavat, että varsinkin edistyneemmät suomenoppijat pystyvät luomaan tekstiin esimerkiksi kontrastiivisen, vakuuttelevan tai reaktiivisen sävyn sanajärjestystä varioimalla. Ilmiölauseen e-subjektia käytetään toisinaan verbinetisenä reemana, mutta verbinetisellä e-subjektilla on myös temaattista käyttöä.

Suomen sanajärjestyksen variaatioon on syytä kiinnittää opetuksessa huomiota. Taitavalla kielenkäyttäjällä on oltava tarpeeksi tietoa sanajärjestyksen tunnusmerkkisyydestä sekä erilaisten sanajärjestysvaihtoehtojen käytöstä ja tehtävistä tekstissä. Sitä, millaisia sanajärjestysvariantteja esimerkiksi oppimateriaaleissa esiintyy tai miten sanajärjestystä tai lauseen ja tekstin informaatiorakennetta kielenopetuksessa käsitellään, ei liene laajemmin selvitetty. ISK:n (2004: 1306-1345) kenttäkuvauksen kaltainen, perinteiset lauseenjäsenkategoriat ylittävä lähestymistapa voisi olla opetuksessakin varteenotettava vaihtoehto tutustua suomen sanajärjestyksen tunnusmerkkisyyteen ja variaatioon. Toisaalta kenttäkuvauksen ongelma on, että lausekkeiden sijoittuminen eri kenttiin ei aina ole 
yksiselitteistä. Esimerkiksi juuri reema-alkuisissa lauseissa teemapaikan ja esikentän täyttyminen voi olla tulkinnanvaraista (vrt. ISK 2004: 1327) ja tulkinta vaatii laajempaa kontekstia, mikä tässäkin artikkelissa tuli ilmi.

Suomenoppijalle tärkeintä lienee lauseen ja tekstin teeman (sekä mahdollisten sivuteemojen) hahmottaminen. Esikentän avulla taas voi ainakin nyt käsiteltyjen ilmiölauseiden tapauksessa hyvin hahmottaa sanajärjestyksen tunnusmerkkisyyttä ja tehtäviä tekstissä.

\section{Kiitokset}

Kiitän artikkelin nimettömiä arvioijia hyödyllisistä kommenteista sekä Jyväskylän yliopistoa mahdollisuudesta käyttää Cefling-aineistoa.

\section{Lähteet}

EVK 2012 = Eurooppalainen viitekehys: Kielten oppimisen, opettamisen ja arvioinnin yhteinen eurooppalainen viitekehys ['A Common European Framework of Reference for Languages']. Council of Europe. 1.-5. painos. Käännös: Irma Huttula, Hanna Jaakkola. Helsinki: Sanoma Pro Oy.

Hakanen, Aimo 1972. Normaalilause ja eksistentiaalilause ['Normal sentence and existential sentence']. - Sananjalka 14, 36-76.

Hakulinen, Auli 1975. Sanajärjestyksen eri tehtävistä ['On the different roles of word order']. - Virittäjä 79, 85-92.

Hakulinen, Auli 2001 [1976]. Suomen sanajärjestyksen kieliopillisista ja temaattisista tehtävistä. - Lea Laitinen, Pirkko Nuolijärvi, Maria Vilkuna, MarjaLeena Sorjonen (Toim.), Auli Hakulinen. Lukemisto: Kirjoituksia kolmelta vuosikymmeneltä. Suomalaisen Kirjallisuuden Seuran toimituksia 860. Helsinki: SKS.

Huumo, Tuomas 1997. Lokatiivit lauseen semanttisessa tulkinnassa: ajan, omistajan, paikan ja tilan adverbiaalien keskinäiset suhteet suomen kielessä ['Locatives and Semantic Interpretation of the Sentence: On mutual relations of adverbials indicating time, possession, space and (internal) state in Finnish']. Turun yliopiston suomalaisen ja yleisen kielitieteen laitoksen julkaisuja 55. Turku: Turun yliopisto.

Huumo, Tuomas, Jari Perko 1993. Eksistentiaalilause lokaalisuuden ilmaisijana ['The existential sentence as an indicator of location']. - Virittäjä 97, 380399. 
ISK = Hakulinen, Auli, Maria Vilkuna, Riitta Korhonen, Vesa Koivisto, TarjaRiitta Heinonen, Irja Alho 2004. Iso suomen kielioppi ['Grammar of Finnish']. Suomalaisen kirjallisuuden seuran toimituksia 950. Helsinki: SKS.

Ivaska, Ilmari 2009. Eksistentiaalilauseen ilmiasut edistyneiden suomenoppijoiden kirjoituksissa. Pro gradu -tutkielma. Turun yliopiston suomalaisen ja yleisen kielitieteen laitos.

Ivaska, Ilmari 2010. Mitä syntaktisesti koodattu korpus voi kertoa sanajärjestyksestä? Predikaatti ja subjekti edistyneiden suomenoppijoiden eksistentiaalisissa lauseissa ['What can a syntactically encoded corpus reveal about word order? Predicate and subject in the existential sentences of advanced learners of Finnish']. - Pille Elson, Katre Õim (Toim.), Korpusuuring ja meetodid. Tallinna ülikooli eesti keele ja kultuuri instituudi toimetised 12 . Tallinn, 37-58.

Kajander, Mikko 2013. Suomen eksistentiaalilause toisen kielen oppimisen polulla ['Paths of learning Finnish existential sentences']. Jyväskylä Studies in Humanities 220. Jyväskylä: Jyväskylän yliopisto.

Martin, Maisa, Sanna Mustonen, Nina Reiman, Marja Seilonen 2010. On becoming an independent user. - Inge Bartning, Maisa Martin, Ineke Vedder (Eds.), Communicative Proficiency and Linguistic Development: Intersections between SLA and Language Testing Research. Eurosla Monographs Series 1. European Second Language Association, 57-80. http://www. eurosla.org/monographs/EM01/57-80Martin_et_al.pdf (26.5.2016).

Seilonen, Marja 2013. Epäsuora henkilöön viittaaminen oppijansuomessa ['Indirect references in Finnish learner language']. Jyväskylä Studies in Humanities 197. Jyväskylä: Jyväskylän yliopisto.

Shore, Susanna 2008. Lauseiden tekstuaalisesta jäsennyksestä ['The textual organisation of clauses']. - Virittäjä 112 (1), 24-65.

Toikka, Anni 2012. Partikkelit, niiden käyttö ja paikka edistyneiden suomenoppijoiden kirjoituksessa. Pro gradu -tutkielma. Turun yliopiston kieli- ja käännöstieteiden laitos, suomen kieli ja suomalais-ugrilainen kielentutkimus.

Vilkuna, Maria 1989. Free Word Order in Finnish. Its Syntax and Discourse Functions. Suomalaisen kirjallisuuden seuran toimituksia 500. Helsinki: SKS.

Vähämäki, K. Börje 1984. Existence and Identity. A Study of the Semantics and Syntax of Existential Sentences in Finnish. Publications of the Research Institute of the Åbo Akademi Foundation. Åbo Akademi. 


\title{
On the variation of word order in written L2 Finnish
}

\author{
MIKKO KAJANDER \\ University of Vienna
}

Finnish word order is known to be syntactically relatively free, but it also has many discourse-conditioned functions (Vilkuna 1989: 9) that form part of the linguistic competency of Finnish native speakers. For those learning Finnish as a second language it can be difficult to recognize which word order is neutral (unmarked) and what interpretation would be triggered using another, rarer (marked) word order in a specific context.

In this paper I concentrate on the Finnish existential ('there is') sentences, which were gleaned from the so-called Cefling corpus (cf. Martin et al. 2010) containing texts written by two groups: adults and school children. The texts in this corpus were judged as being of levels A1-C2 (adults) and levels A1-B2 (school children) with regard to the Common European Framework of Reference for Langugages (CEFR).

The most typical word order of the existential sentences is that in which the theme position of the sentence is occupied by a local or possessive adverbial and the subject of the sentence is post-verbal (AVS for short). The theme position can also be empty (VS). Both of these word orders are also unmarked. First, I analyzed the variation of the (A)VS word order statistically. The marked variations of the (A)VS word order become more common, as the writing skills (according to CEFR levels) increase. Statistically highly significant differences were found between the levels A \& B as well as between the levels B \& C in the adult group. The variation in the school children group was not statistically significant.

I then analyzed more closely the use of the marked SV-order in text context, using the so-called field description of word order ('sanajärjestyksen kenttäkuvaus') as presented in the ISK (2004: 1306-1345). (Cf. Vilkuna 1989 for the nearest equivalent of this model in English.) The unmarked VS-order sentence is sometimes considered as being "themeless", since the theme field is not occupied. If the theme field is empty, the subject in the SV-type sentence could 
occupy the theme field. But also the so-called pre-field preceding the theme field could be occupied by the subject, if the theme field were not really empty. This might seem marginal, but could also have an influence on the interpretation of the sentence in context.

The text samples reveal that a suitable theme can often be found for the empty theme slot - at least in the case of SV-order - in the text preceding this sentence. In this case the "empty" theme field could be occupied by this continuous theme, and the subject (rheme) would be in the pre-field. This word order is clearly marked and brings a contrastive or a convincing tone to the text. The text samples show that at least some of the higher-level L2 Finnish learners are able to use the marked SV order in texts this way quite correctly.

The subject of the existential sentences is normally interpreted as a rheme or "new information". In some cases, however, the text samples show that the subject of the existential SV sentence is not actually always a rheme in the prefield: it has been at least indirectly mentioned in the text before and perhaps that is why it rather seems to occupy the theme slot in some SV-order existential sentences. There are also some specific verbs with which the SV-order in the existential sentences seems to be well-established without necessarily being the marked order. This, as well as some learning-related issues of word order, requires further investigation.

Keywords: L2 Finnish, existential sentence, information structure, CEFR, Cefling

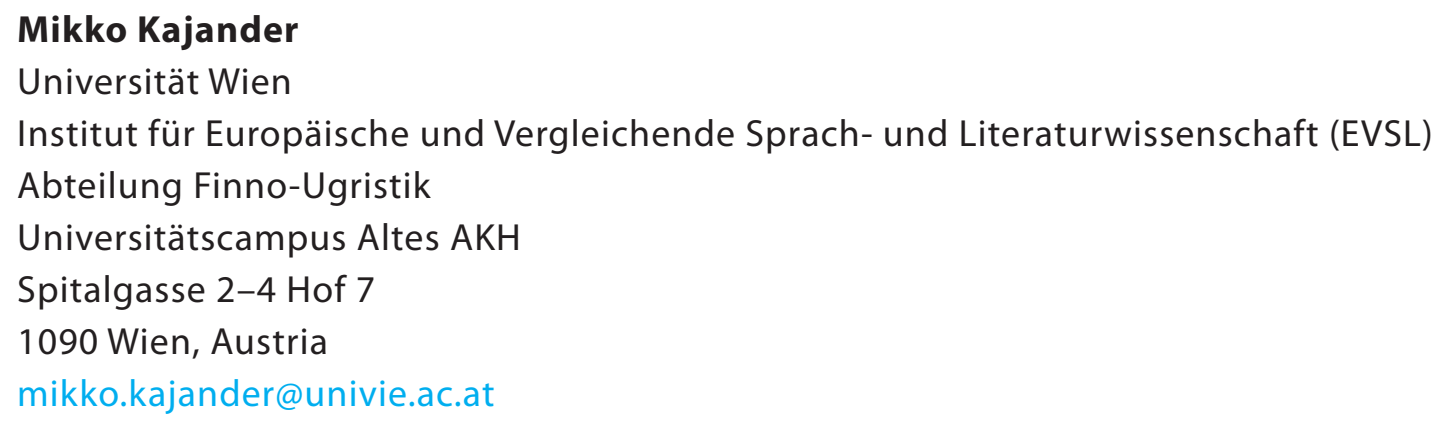

